\title{
Transport policy planning in Germany - An analysis of political programs and investment masterplans
}

\author{
Frank Fichert ${ }^{1}$ (D)
}

Received: 27 October 2016 / Accepted: 9 May 2017 / Published online: 17 May 2017

(C) The Author(s) 2017. This article is an open access publication

\begin{abstract}
Introduction In Germany, the most recent comprehensive transport policy program of the federal government was published in the year 2000, followed by several sector specific programs. Aims, strategies, and priorities specified in the different governmental transport policy documents are discussed in the paper, with a particular focus on the modal split between road and rail. Apart from the fiscal and the regulatory framework, the most important policy area for the federal government is the provision of transport infrastructure. In 2016, the federal government enacted a new investment masterplan. Therefore, the experience with the former plan is described and key elements of the new masterplan are presented. The overall investment into transport infrastructure as well as the share of the different modes of transport are analyzed in more detail. Methods Germany's transport policy is analyzed based on the aims, strategies, and priorities which are expressed in the published programs (text analysis). Data on modal split and user costs is used to assess transport policy developments. The infrastructure masterplans are analyzed based on the planned allocation of investment for different modes of transport and types of investment. Moreover, for the past masterplan actual budget data is used for the analysis.

Results With respect to transport policy programs, a shift in the priorities can be observed, closely linked to the changing political majorities. Whereas the comprehensive program
\end{abstract}

This article is part of Topical Collection on The development of National Transport Policy

Frank Fichert

Fichert@hs-worms.de

1 Faculty Tourism and Transportation, Worms University of Applied Sciences, Erenburgerstraße 19, D-67549 Worms, Germany published in 2000 stresses the importance of a sustainable development and calls for a modal shift, more recent programs focus on the competitive situation of German transport service providers. Moreover, more emphasis is put on the implementation of specific measures. With respect to infrastructure provision, in particular investment into road infrastructure was below the planned values. The recently enacted plan allocates more funds to the maintenance and replacement of infrastructure, and to inland waterways.

Conclusions Although the priorities set by the government in published transport policy programs have changed, the effects on the overall traffic development remain rather limited. With respect to the federal transport infrastructure masterplan, an overestimation of the number of projects which might be completed within the given timeframe has been criticized several times. Although the political progress is providing some incentives to include a high number of projects in the masterplan, a more realistic approach appears to be suitable, also signaling the need for a larger budget. In the past, budget increases have been the result of macroeconomic considerations rather than of transport policy requirements. It remains to be seen whether these deficits will be at least partially eliminated during the lifespan of the recently enacted masterplan.

Keywords Infrastructure investment · Transport policy · Cost benefit analysis

\section{Introduction}

Transport policy provides several areas for long-standing debates. Especially in the second half of the twentieth century, many economists argued in favor of liberalizing the heavily regulated transport sector (for Germany see [29]). Today, at least in industrialized countries major transport markets are 
competitive (or at least subject to tendering procedures, e.g. local public transport), leaving only limited opportunities for further deregulation. However, the fiscal framework (i.e. taxes, subsidies, and user charges) plays an important role for developments in the transport sector, giving rise to several controversies. Moreover, almost the entire transport infrastructure is provided by the state. Therefore, not only the overall level of investment but also the allocation of funds between the different modes of transport and the resulting effects on the modal split are key elements of debates on transport masterplans. Already in 1953, the first comprehensive West German transport policy program called for a 'harmonic sharing of tasks' between the different modes of transport ([18], own translation). Against the background of a growing importance of climate change policies and differences in the specific $\mathrm{CO}_{2}$ emissions of road and rail transport, the debate on modal split developments is getting more intense over the last years (e.g. [4]).

Due to the country's federal structure and the high importance of the European regulatory framework, transport policy planning in Germany is rather complex. Despite the integration into the European transport policy framework, several decisions are still within the competencies of domestic policy makers, especially with respect to infrastructure provision and several elements of the fiscal framework. Whereas many recent papers on specific aspects of Germany's transport policy exist, papers with a broader focus on Germany's transport policy for the period after reunification are scarce (one exception is [40], for an earlier comprehensive assessment see [5]) and some of them were only published in German language.

In this paper, recent policy programs as well as the masterplan for investment into the federal transport infrastructure will be discussed, giving particular attention to aims and decisions related to the modal split, and concentrating on the period after reunification in 1990. The paper starts with a short overview of the allocation of transport policy competencies, the different 'historic' phases of transport policy developments in Germany, and an overview of the current federal road and rail infrastructure provision (section 2). In section 3, recent policy programs published by the government are analyzed, starting with the integrated transport policy program published in 2000 . Section 4 provides an overview of infrastructure investment masterplanning, concentrating on major controversies and actual developments. Finally, section 5 concludes.

\section{Basic information on transport policy and transport markets in Germany}

\subsection{Competencies for transport policy decisions and infrastructure provision}

In Germany the 'vertical' allocation of political competencies on the different levels of the state is determined by the constitution ('basic law' - Grundgesetz). With regard to the regulatory framework, air transport and the federal railways are exclusively in the jurisdiction of the federal state ('Bund'). Moreover, the federal state may decide to establish a uniform regulatory framework for maritime shipping, inland navigation, road traffic (including user charges), and non-federal railways. In practice, the regulatory framework for each of these areas is dominated by federal laws and regulations. On the other hand, the states ('Länder') are responsible for regional and local public transport. Some states have further decentralized these competencies, especially with respect to regional and local bus services. For most areas, regulations and directives of the European Union provide a rather tight framework for transport policy decisions.

The responsibilities for infrastructure provision also depend on the mode of transport. Every road in Germany is classified according to its user structure. The federal level is in charge of roads which are predominantly used for interstate traffic, with a further differentiation between federal motorways ('Bundesautobahnen') and federal highways ('Bundesstraßen'). Whereas all expenses for those federal roads are financed through the federal budget, the tasks of planning, building and maintaining those roads are assigned to the states, leading to some principal-agent-issues [36]. In 2016, the federal government and the states agreed in principle on transferring some of these competencies to a new federal infrastructure authority [20]. The states are solely responsible for roads which are important for interregional traffic ('Landesstraßen' and 'Staatsstraßen'), whereas all other roads of only local importance have to be provides by counties and cities, respectively.

Almost the entire railway infrastructure is owned and operated by DB Netz AG, a branch of the federal railroad company Deutsche Bahn AG (DB). DB is formally privatized but $100 \%$ owned by the federal state. Only small parts of the railroad infrastructure with regional or local importance belong to railroad infrastructure companies owned by states or local municipalities. Also the largest part of the infrastructure for inland navigation has to be provided and maintained by the federal government. With airports and seaports, the situation is more diverse. In 2016, 17 German airports served more than $1 \mathrm{~m}$ passengers per year. Only four of them are partially privatized, one low-cost airport is almost completely owned by a private investor. The other twelve airports are in full public ownership. Whereas the federal government is holding shares of the airports in Munich, Cologne-Bonn, and Berlin, all others airports are owned by states and or municipalities in different combinations. The large German seaports are owned by the cities (taking into account that two of those cities, Hamburg and Bremen, are states). In some cases the operators are partially privatized. Inland ports are usually owned by cities.

On the federal as well as on the state level, competencies which are relevant for transportation usually are allocated to 
different ministries. The following two examples show (potential) conflicts within the government. Since the federal ministry of finance is in lead for all decisions on indirect taxes, the federal ministry of transport's opposition against the German air transport tax, introduced in 2011, so far has not been successful. On the state level, the ownership rights for airports are usually executed by the ministries of finance, whereas the state ministries of transport serve as economic regulators. Therefore, the decision of the ministry of transport in the state of Hessen, not to approve an increase of Frankfurt airport's user charges for 2016 [31] might have some potentially detrimental effects on the state budget.

\subsection{Historic phases of transport policy in Germany}

Because of the large degree of path dependency in transportation, the main historic developments of Germany's transport policy are briefly sketched in this subsection [28]. The German railroad system was already nationalized in the late nineteenth century, contributing with its profits to the state budget. The upcoming of road haulage in the late 1920s led to a severe economic regulation of this sector, intending to protect the state-owned railway operator from the new intermodal competitors.

After 1945 the system of limited entry ('concessions') and minimum prices for road haulage was sustained. With respect to aviation, Germany was not allowed to provide air transport services for several years after the end of World War II. The airline Deutsche Lufthansa was re-founded in 1955 as a state owned company. The separation of Germany into two states in 1949 led to severe challenges for infrastructure provision. Damages caused by the war had to be repaired, links to the former capital Berlin were capped, and new connections between the northern and the southern parts of West Germany had to be established. The rapid economic recovery ('Wirtschaftswunder' - 'economic miracle') made mass motorization possible. As a consequence, in the passenger transport markets the railway system as well as the local public transport operators lost a large portion of their customers. Therefore, in the 1960s and 1970s huge investments into the federal motorway and highway system (in order to reduce congestion) were paralleled by a demolishing of railroad lines in rural areas and tram systems in many cities. On the other hand, commuter rail systems have been extended in densely populated areas since the 1970s.

In the 1980s the positive experience with deregulated transport markets in countries like the US and the UK as well as an increasing pressure from the European Communities (EC) to also open transport markets for firms established in other EC member states led to a change in the German transport policy. The markets for air transport services as well as for road haulage have been liberalized, following a step-wise approach. Deutsche Lufthansa was fully privatized. The implementation of the European railway packages facilitated competition in railway markets. According to the Rail Liberalization Index, only Sweden and the UK show a higher degree of liberalization than Germany $[32,33]$. DB provides rail as well as several other transport services (regional and local bus transport, worldwide logistics via its branch DB Schenker). In 2015, DB's market share was $61 \%$ (based on ton kilometers) in rail cargo and $71 \%$ (based on train kilometers) in regional passenger rail transport [22]. There is hardly any competition in the long-haul passenger market. Against this background, the Monopolies Commission (an independent advisory body to the German government and parliament) recommends a full vertical separation between infrastructure and operation in order to foster competition in the railway sector [38]. The prohibition of scheduled long-haul bus services, which had been introduced in the 1930s to protect the railroad operator, lasted until the year 2013 [23]. Since then, the market for scheduled long-haul bus services has shown a tremendous growth [2].

German reunification in 1990 was followed by huge investments into the totally run down transport infrastructure in East Germany as well as a resurrection of links between the eastern and the western part of the country. Already before reunification, the environmental effects of transportation had gained increasing attention. Whereas the first measures basically aimed at emission reductions by improved technology (e.g. mandatory catalytic converters for new cars), towards the turn of the century also financial incentives have been used to a greater extent (e.g. increasing tax on fuel in 1999-2003 ('eco tax'), see also section 3.1).

Also in the late 1990s financing of transport infrastructure became more challenging. In order to get closer to a balanced budget, investments into infrastructure have been reduced in general, but were increased during economic downturns, especially in the year 2009 (see section 4). In 2005 a mileagebased user charge for trucks (heavy goods vehicles - HGV) on federal motorways replaced the toll sticker introduced in 1995 (see also section 3.1).

\subsection{Key determinants for transport policy decisions}

The following facts, political priorities, and developments are crucial for understanding and assessing transport policy decisions in Germany:

- Germany is characterized by a high degree of motorization, also leading to a rather high political attention for transport policy decisions affecting car users. As of January 2016, $45.1 \mathrm{~m}$ cars were registered in Germany (data source: [35]). Given a population of approximately $81 \mathrm{~m}$, this is a relation of 0.56 cars per inhabitant, which is above the EU-28 average ( 0.49 cars per inhabitant in 2013, data source: [24]). Amongst the five largest EU member states (in terms of population), only Italy has a 
higher motorization than Germany. Since 2008, vehicles temporarily registered as 'off the road' (e.g. convertibles during winter) are not included in the German registration data, reducing the reported number of registered cars by more than five million in 2008 when compared to 2007.

- Not only because of its strong industrial basis but also due to its geographic position, logistics and especially road haulage play an important role in Germany. Almost $5 \mathrm{~m}$ trucks (light as well as heavy goods vehicles) are registered in Germany (data source: [35]). A high and increasing share of trucks on German motorways is operated by foreign companies (40\% of total mileage in 2015), especially transporting goods between eastern and western Europe, as well as between northern and southern Europe [3].

- For building new infrastructure, Germany has rather strict regulations regarding environmental protection. Furthermore, a participation of the citizens as well as of many Non-governmental organizations (NGOs) in the planning process is required [17]. This typically leads to a rather long duration of planning processes as well as relatively high costs of providing infrastructure. Also in other areas, e.g. night curfews at airports, German regulations are stricter than in many other European countries.

- Within the framework of European climate policy, Germany has set targets for reducing $\mathrm{CO}_{2}$ emissions which are above the European average [26]. Since the transport sector is one of the largest sources of $\mathrm{CO}_{2}$ emissions, this political aim also affects transport policy.

- From a demographic point of view, the German population is aging and shrinking [27]. This process is far more advanced in rural areas than in larger agglomerations, where even population growth can be observed. Therefore, for rural areas the provision of public mobility options is an important political aim

\subsection{Key characteristics of federal road and rail infrastructure in Germany}

In 2015, the entire road network's length in Germany was more than $680,000 \mathrm{~km}$. The share of the federal motorways was $1.9 \%$, the share of federal highways $5.8 \%$, and the share of the state roads $12.7 \%$ [15]. Figure 1 shows that the network length of federal highways increased by $20 \%$ since reunification, whereas the network length of the federal highways decreased by $10 \%$. Since the highway network is significantly larger than the motorway network, the length of the entire federal road network decreased by $3.3 \%$. One reason is the downgrading from federal highways to state roads, especially after the construction of new motorways running parallel to existing highways.

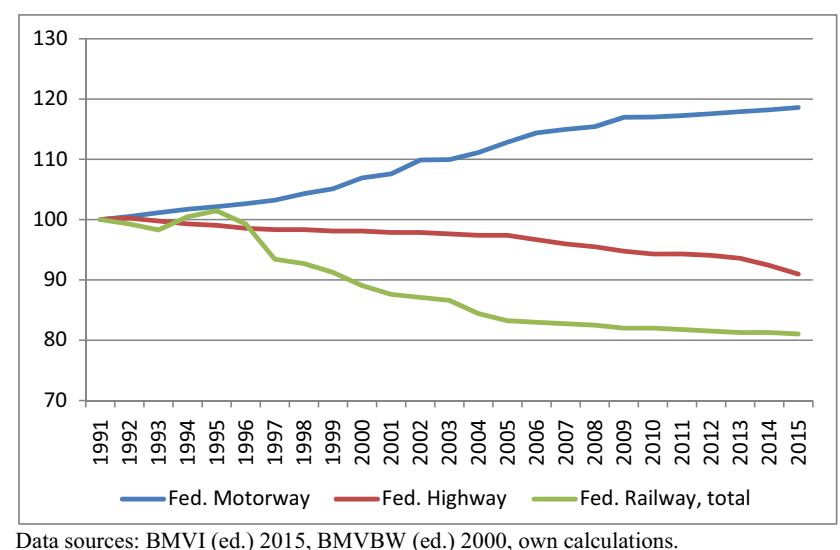

Fig. 1 Development of federal motorway, highway, and railway network length, 1991-2015 $(1991=100)$

As many motorways were built in the 1970s and today's traffic volume exceeds by far the numbers which have been forecasted in that period, significant parts of the infrastructure are 'worn out'. Therefore, an increasing share of infrastructure funding has to be allocated to repairing and replacing infrastructure rather than expanding it (see section 4). The 'level of modernity' for the entire road infrastructure (defined as the relation between the current asset value and the acquisition values) decreased from 0.70 in 1991 to 0.66 in 2015 [13, 15].

Since reunification, the total length of the federal rail network decreased by almost $20 \%$ (see Fig. 1). However, the quality of the rail infrastructure increased significantly, e.g. due to an increase of electrified segments by almost $25 \%$. In 2015 , more than $60 \%$ of the federal rail network was electrified. In 1989, the first high speed trains began their services in West Germany. Since the 1990s the high speed rail (HSR) network has been extended and the number of trains has been increased. Quite recently, cross border connections (e.g. Frankfurt-Paris and Frankfurt-Brussels) became part of the HSR network.

\section{Governmental transport policy programs}

\subsection{Integrated transport policy program (2000)}

Like in all other political sectors, transport policy programs reflect the aims of political parties and their representatives. Therefore, a change in the composition of the government is likely to influence political priorities. The federal elections in 1998 led to a new government, replacing the coalition between the Christian-democratic and the liberal party, which had had the majority in parliament since 1982. The government elected in 1998 was formed by the socialdemocratic party and, for the first time in German history, the 'green' party. 
The 1998 government stressed the importance of reducing detrimental effects of transportation not only by technological improvements but also by shifting the modal split towards more environmental friendly modes of transport as well as by reducing (motorized) traffic. The overall target was a 'sustainable' transport sector, balancing economical, environmental and social aspects. One new approach towards a more sustainable transport system was the integration of the formerly separated ministries for transport, and for building and regional planning into one joint ministry, led by a member of the social-democratic party.

In 2000 the ministry published a transport policy program entitled 'Transport report 2000. Integrated transport policy Our concept for future mobility' (BMVBW 2000, own translation). This comprehensive document analyses past developments, defines political targets, and describes ten key areas for transport policy. Some of them basically update undisputed programs like infrastructure reconstruction in East Germany, and further improvements in transport safety. Others show at that time new priorities, especially the integrated approach of land use planning and transport policy, and the general call for a more environmental friendly transport policy.

Although the program explicitly named some measures and instruments, no quantitative targets were set. However, the government also commissioned a transport forecast which included three different scenarios: (1) A 'business as usual' scenario, assuming that the transport policy of the year 1997 (i.e. before the change in government) remains unchanged, (2) an 'excessive demands' scenario which assumed a strong increase in user costs in order to achieve ambitious environmental targets but appeared to be unrealistic from a political perspective, and (3) an 'integrated scenario' which was based on the government's integrated approach towards transport policy. The integrated transport policy scenario assumed on the one hand a slight increase in real user costs for road traffic (passenger and freight) as well as for air transport, and on the other hand reduced real user costs for railway services. In order to have a uniform measure, proposed regulatory changes, e.g. strengthening of working time limitations for truck drivers, were transformed into cost increases. It is shown in Table 1 that still an overall traffic growth was assumed, but also a slight change in the modal split as a result of the integrated transport policy approach.

Since the year 2000, Germany has seen three changes in the composition of the federal government. In 2005 the coalition between the social-democratic and the green party was replaced by the so-called 'large coalition' between the Christian-democratic party and the social-democratic party. The minister of transport was still a member of the socialdemocratic party. After the 2009 elections, the government was formed by the Christian-democratic and the liberal party, succeeded in 2013 by another 'large coalition'. Since the year 2009 the minister for transport has been a member of the
Christian-social party (i.e. the Bavarian branch of the Christian-democratic party). In 2013, the structure of the government was re-organized. The merger of the transport ministry with the ministry of building and regional planning was reversed. In the current government, the minister of transport is also in charge of 'digital infrastructure'. The minister for environmental protection is also responsible for building and regional planning.

A comparison between the actual traffic development and the different scenarios prepared for the integrated transport policy program might be used for assessing the overall effect of transport policy decisions over the respective period. Table 2 shows the growth rates of transport services provided and the changes in the modal split between 1997 and 2014 (actual data)/2015 (scenario forecast published in 2000). Especially with respect to road traffic, the actual development of traffic growth rates comes closer to the integrated transport policy (INT) scenario forecast than to the business as usual (BAU) scenario forecast. However, the changes in the modal split are closer to the BAU scenario than to the INT scenario. Since the total amount of traffic is also determined by external factors (especially the overall economic development including the severe recession in the year 2009) the changes in the modal split are a better indicator for the effects of transport policy decisions.

At first sight, the targets of an integrated transport policy, as determined in the year 2000, have not been reached. However, there are several factors which have to be taken into account when comparing the scenario forecasts with actual developments. First, published data on car traffic (pkm) is derived from passenger transport models. In 2002, these models were updated based on new data on transport behavior [34], reducing the intertemporal comparability of this indicator. Second, although the government's transport policy program published in the year 2000 has never been officially revoked, political priorities may have changed several times since the year 2000 due to the changes in the government. For example, the coalition agreement between the parties forming the new federal government in 2009 explicitly stated that the transport policy of the former coalition between the social-democratic and the green party 'belongs to the past' ([21]: 34, own translation).

The increase of user costs for road traffic, which was a key element of the integrated transport policy approach, was only partially supported by fiscal policy: The quantity tax on fuel was increased five times between 1999 and 2003 (each time by $3.07 \mathrm{ct} / 1$, i.e. in total by $15.35 \mathrm{ct} / \mathrm{l})$ but is constant since 2003, leading to a real reduction of the tax rate after 2003 . However, the rate of the user charge for trucks on the federal motorway network was increased significantly in 2009 (the average rate increased from $12.4 \mathrm{ct} / \mathrm{km}$ to $16.3 \mathrm{ct} / \mathrm{km}$, see [25]) and the part of the network for which the user charge is levied was increased in 2012 and in 2015. 
Table 1 Transport services provided in Germany - Actual data for 1997, and two scenarios for 2015

\begin{tabular}{|c|c|c|c|c|c|c|}
\hline & \multicolumn{3}{|c|}{ Transport services provided (bn pkm/tkm) } & \multicolumn{3}{|c|}{ Modal split (\%) } \\
\hline & 1997 & 2015 BAU & 2015 INT & 1997 & 2015 BAU & 2015 INT \\
\hline \multicolumn{7}{|l|}{ Passenger } \\
\hline - Road & 750 & 915 & 873 & 79.6 & 79.2 & 72.8 \\
\hline - Rail & 74 & 87 & 98 & 7.8 & 7.5 & 11.7 \\
\hline - Other public & 83 & 76 & 86 & 8.8 & 6.6 & 8.8 \\
\hline - Air & 36 & 78 & 73 & 3.8 & 6.7 & 6.7 \\
\hline Total & 943 & 1156 & 1130 & 100.0 & 100.0 & 100.0 \\
\hline \multicolumn{7}{|l|}{ Freight } \\
\hline - Road & 236 & 422 & 374 & 63.6 & 69.4 & 61.5 \\
\hline - Rail & 73 & 99 & 148 & 19.6 & 16.3 & 24.3 \\
\hline - Water & 62 & 87 & 86 & 16.8 & 14.3 & 14.2 \\
\hline Total & 371 & 608 & 608 & 100.0 & 100.0 & 100.0 \\
\hline
\end{tabular}

(BAU - business as usual and INT - integrated transport policy)

Source: BMVBW (2000), p. 25

In total, the costs of private car use increased by $28.9 \%$ between 2000 and 2015 (own calculations based on [15]: 293), which is slightly above the overall inflation rate in this period (24.7\%; own calculations based on [41]). Between 2005 and 2015 the increase in costs of private car use even was below the inflation rate $(14.7 \%$ vs. $15.6 \%$; sources as indicated above). On the other hand, the price index for passenger rail services increased by almost $50 \%$ between 2000 and 2015 (own calculations based on [15]: 289).

For freight transport no data on the cost of service provision is publicly available for the period 2000-2015. The producerprice-index (PPI) can be used as a proxy for cost developments, however it only covers German transport service providers, i.e. the large (and growing) number of foreign trucks on German motorways is not included. Moreover, it is only published since 2006. In the period 2006-2015 the PPI for rail cargo services increased by $23.8 \%$, whereas the increase of the PPI for road haulage only was $11.5 \%$ ([42], own calculations).

\subsection{Policy programs for freight transport and logistics after the year 2000}

Official transport policy documents published after the year 2000 only refer to specific market segments or particular modes of transport. Several policy documents focus on the cargo

Table 2 Comparison of actual transport developments and former scenario forecasts

\begin{tabular}{|c|c|c|c|c|c|c|}
\hline & \multicolumn{3}{|c|}{ Average growth rates (1997-2014/2015) } & \multicolumn{3}{|c|}{ Change in modal split (\%-points) } \\
\hline & Actual & 2015 INT & 2015 BAU & Actual & 2015 INT & 2015 BAU \\
\hline \multicolumn{7}{|l|}{ Passenger } \\
\hline - Road & 0.7 & 0.8 & 1.1 & -1.4 & -6.8 & -0.4 \\
\hline - Rail & 1.3 & 1.6 & 0.9 & 0.6 & 3.9 & -0.3 \\
\hline - Other public & 0.3 & 0.2 & -0.5 & -0.7 & 0.0 & -2.2 \\
\hline - Air & 2.9 & 4.0 & 4.4 & 1.5 & 2.9 & 2.9 \\
\hline Total & 0.8 & 1.0 & 1.1 & & & \\
\hline \multicolumn{7}{|l|}{ Freight } \\
\hline - Road & 2.6 & 2.6 & 3.3 & 4.1 & -2.1 & 5.9 \\
\hline - Rail & 2.5 & 4.0 & 1.7 & 0.8 & 4.7 & -3.3 \\
\hline - Water & -0.3 & 1.8 & 1.9 & -4.9 & -2.6 & -2.5 \\
\hline Total & 2.2 & 2.8 & 2.8 & & & \\
\hline
\end{tabular}

(BAU - business as usual and INT - integrated transport policy)

Source: BMVBW [12], p. 25, BMVI (ed.) [15], own calculations 
segment and will be discussed in this subsection. Just like the integrated transport policy program from 2000, the freight transport and logistics masterplan from 2008 highlights the importance of a sustainable development of the transport sector. The masterplan sets out six key objectives and for each of these objectives, specific measures are assigned. In contrast to the integrated transport program, the masterplan was based on extensive ex ante discussions with stakeholders. Table 3 provides an overview of objectives and assigned measures.

Comparing the Freight transport and logistics masterplan with the integrated transport policy program enacted eight years before, the masterplan puts more emphasis on the competitiveness of the German freight transport and logistics industry. At the same time, more attention is given to working conditions which might be attributed to the specific priorities of the social-democratic party, which led the ministry at that time, but may also be a consequence of the intensified international competition, especially by logistic service providers from Eastern Europe after the EU enlargement in 2004 and 2007, respectively. Unlike the previous transport policy program the masterplan of 2008 names responsibilities as well as implementation periods. In many cases, an immediate action was aspired. However, some of the measures refer to developing concepts rather than implementing specific measures.

In 2010, the new government formed by the Christiandemocratic and the liberal party issued an 'action plan freight transport and logistics' [8], updating the masterplan published two years ago. According to its introduction, the priority of the action plan, in comparison to the masterplan, is more on enabling mobility and less on reducing mobility. Most measures have been basically updated, some approaches, e.g. referring to the internalization of external costs, have been abandoned, whereas other measures, e.g. enabling mega trucks ('giga-liner') on German roads, were added. Already in 2011, the ministry published a first report on the implementation of the measures covered by the action plan [9]. In 2012, the ministry released another intermediate assessment [10], claiming that already one fourth of the measures included in the action plan have been implemented and most other measures are 'on track'.

Another update of the action plan was published in 2015 [16]. The ministry, still led by a member of the Christiansocial party, claimed that many measures of the former action plan have been successfully implemented. As a response to new challenges, the ministry refers to (1) increased investment into infrastructure, based on a higher share of user fees, (2) promoting innovations like alternative fuels and (3) digitalization, e.g. automated driving.

\subsection{Other transport policy programs after the year 2000 and intermediate conclusions}

Several transport policy programs have been developed after the year 2000 with a focus on certain infrastructures or specific modes of transport, e.g. the airport concept of the federal government (2009, updating the first airport concept from 2000), the federal seaport concept (2009), the national plan for bicycle traffic (first version 2002, second version 2012), and the air transport concept (announced for 2017). As a particularity, the national plan for bicycle traffic specifies a 'possible' share of bicycle traffic in 2020. However, it has to be taken into account that the potential influence of the federal government with respect to the promotion of bicycle traffic is rather small.

In addition to federal policy programs, some states published transport policy masterplans for their jurisdictions. A rather recent and comprehensive program was developed by the state of Baden-Württemberg [37]. This masterplan is based on several traffic forecasts and studies commissioned by the government. The key target is a sustainable transport development. The masterplan describes several measures and priorities for the government's transport policy, especially with respect to investment into the state roads, public transport systems, and Stuttgart airport. However, due to the allocation of competencies, in several cases the state government could only announce that it will try to influence the federal government to take certain measures. Moreover, the coalition between the Christian-democratic and the liberal party in the state of Baden-Württemberg was replaced in 2011, only several months after the publication of the masterplan. Since then, the prime minister as well as the minister for transport is a member of the green party.

To sum up, the development of transport policy programs over the last 20 years clearly shows varying priorities caused by several changes in the composition of the federal government. Whereas in 2000, a rather strong intention to influence traffic developments and in particular to reduce transport activities and influence the modal split could be observed, a more pragmatic and industry oriented approach has been established by subsequent coalitions. Although the implementation of the measures laid down in the action plans is monitored rather closely, the overall target of a sustainable development allows for many different interpretations, making an assessment of the transport policies' output rather difficult.

\section{Federal transport infrastructure investment planning and financing}

Investment into Germany's federal transport infrastructure has always been controversial. On the one hand, the different states and regions within the states compete for a high share in the overall budget (with the exception of some projects which are not wanted by some stakeholders). On the other hand, the allocation of funds between the different modes of transport has been disputed.

In the 1950s and 1960s, no formal procedure for the allocation of federal funds existed. Members of parliament from 
Table 3 Objectives and assigned measures from the federal government's freight transport and logistics masterplan 2008

\section{Objective}

Making optimum use of transport infrastructure shaping transport to make it more efficient

Avoiding unnecessary journeys - ensuring mobility

Shifting more traffic to the railways and inland waterways

Upgrading more transport arteries and hubs

Environmentally friendly and climate-friendly transport

Good working conditions and good training in the freight transport industry

\section{Assigned measures}

1. Develop and deploy more traffic management systems on busy sections of federal motorways

2. Standardize and link up the traffic management systems on federal motorways nationwide

3. Speed up implementation of the "Development programme to increase the number of parking areas at service stations and rest areas on federal motorways"

4. Continue and intensify the measures to tackle congestion by optimizing roadworks management

5. Provide traffic information and communications services for heavy goods vehicles on the motorway network by using toll information (value-added services)

6. Develop a strategy to speed up introduction of the European Train Control System (ETCS) on freight corridors in Germany

7. Develop a national ports strategy

8. Develop a national airports strategy

9. Take concerted action with shippers and the freight transport sector to stagger freight traffic (extending ramp times)

10. Create a focal point - the Fed. Government Commissioner for Freight Transport and Logistics

1. Urban Logistics Initiative

2. Step up investment in innovative and capacity-enhancing technologies

3. Optimize transit traffic

4. Short sea shipping

1. Review the regulatory framework for freight transport in intermodal competition

2. Increase funding for combined transport

3. Evolve handling technologies and organization in combined transport

4. Internalize external costs

1. Segregate freight and passenger traffic

2. Review the requirement plans

3. Press ahead with the implementation of PPP solutions for the speedy and efficient delivery of motorway widening and motorway maintenance projects

1. Develop a strategy to vary toll rates according to the route driven and the time of day

2. Mitigate noise on the railways

3. Establish a financial assistance programme to encourage the use of modern technologies to reduce the noise caused by rolling stock

4. Optimize processes in the logistics chain taking greater account of environmental concerns

5. Further tighten environmental and safety standards (emissions reduction, noise mitigation, safety technology)

1. Step up the enforcement of social legislation in the road haulage sector to improve road safety

2. Launch a basic and further training initiative

3. Hold regular summits on the subject of work and training in the freight transport and logistics sector 
Table 3 (continued)

\begin{tabular}{ll}
\hline Objective & Assigned measures \\
\hline & $\begin{array}{l}\text { 4. Launch a lighthouse project to improve the international } \\
\text { profile of logistics courses in higher education }\end{array}$ \\
& $\begin{array}{l}\text { 5. Monitor the working conditions in the freight transport } \\
\text { and logistics sector as part of the market observation }\end{array}$ \\
& activities of the Federal Office for Goods transport \\
6. Improve seafarers' working and living conditions \\
$\begin{array}{l}\text { 1. Establish a freight transport and logistics network } \\
\text { attractive as a centre for logistics even more }\end{array}$ \\
$\begin{array}{l}\text { 2. Implement a marketing strategy to promote Germany as } \\
\text { a centre for logistics }\end{array}$ \\
$\begin{array}{ll}\text { 3. Security strategy for the freight transport and logistics } \\
\text { industry }\end{array}$ \\
\hline
\end{tabular}

Source: BMVBS [7]

different regions tried to influence the ministry, aiming at maximum investment within their respective electoral districts. In order to allocate the budget for transport infrastructure in a more efficient and transparent way, an intermodal investment masterplan for the federal transport infrastructure (Bundesverkehrswegeplan - BVWP) was introduced in the 1970s [30]. This masterplan was updated several times. The following paragraphs focus on the development after German reunification in 1990 .

The basic idea of the federal transport infrastructure masterplan is to invest a predefined (projected) amount of money into the most beneficial projects. Based on project suggestions from the 16 states, railroad operators, and other stakeholders a cost benefit analysis (CBA) is conducted for potential projects, following a uniform approach for all modes of transport. Usually, the masterplan's timeframe is 15 years. Therefore, a 15 year traffic forecast serves as a basis for conducting the CBA. In addition to the CBA, in some areas supplementary studies have to be prepared, analyzing effects which are difficult to valuate (e.g. some environmental aspects).

In order to be included into the masterplan, the benefits of a project have to outweigh its costs. Moreover, priorities are set, differentiating between 'urgent' and 'additional' projects (with some additional classifications within these two categories). 'Urgent' means that the project should be completed within the timeframe of the masterplan. However, the masterplan is not simply composed of the projects with the highest relation between benefits and costs. First, from a political perspective it would not be feasible to only invest into infrastructure located in few states, even if this would be the most beneficial option for the entire economy. Therefore, the federal ministry has to make sure that an 'appropriate' share of the budget is spent in each state. Second, the allocation of the budget onto the different modes of transport matters. Usually some parts of the budget are shifted from road to rail and inland waterway projects, avoiding a 'too high' share of investment into the federal motorways and highways which may lead to an 'unwanted' change in the modal split.

The first masterplan after German reunification dates from 1992 (BVWP 1992), basically including most of the large infrastructure projects which have been important for the economic recovery of Eastern Germany. In 2003 a new masterplan was enacted (BVWP 11), covering all planned investments until 2015 [11]. In March 2016 the government published a first draft of the updated masterplan. After a public consultation process, leading to some smaller changes, the government enacted the masterplan in August 2016. The timeframe of the new masterplan is 2030. Again, the methodology for the CBA has been updated ([44], for a critical discussion see [39]).

Before construction, all infrastructure projects have to be legally approved, including a comprehensive consultation and participation process. If a project is classified 'urgent' in the masterplan, the states have the obligation to start (or continue) the approval process. However, even for projects with a very high cost benefit ratio, difficulties in the planning process as well as legal controversies might significantly delay or even prevent the investment. Anecdotal evidence exists for projects which are part of the federal investment program for several decades but construction has not even started. The masterplan itself does not provide funds, this is done by infrastructure investment decisions made by the parliament (for roads usually the decision of the parliament covers a five years period).

Infrastructure financing in Germany depends on the mode of transport. Apart from some pre-financing through Publicprivate-partnership models (for a critical assessment see [19]), the entire federal road infrastructure is financed through the state budget. The two sources for funding are tax revenues and the net revenues from the $\mathrm{HGV}$ user charge, the later being included into the state budget and earmarked for road infrastructure investment. Also inland waterways are entirely financed through the state budget with rather small revenues from user fees (the river Rhine as the most important 
waterway in Germany is exempted from user fees since 1868). With respect to rail infrastructure, DB Netz AG collects user fees and is not only responsible for operation and maintenance of the federal railway network but also contributes to the financing of investment projects. However, the largest share of infrastructure investment is financed through the federal state's budget, sometimes complemented by funding from the European Union or the German states. Therefore, total investment into the railway infrastructure exceeds the values shown in the state budget and the infrastructure investment masterplans.

Past masterplans have been criticized in the literature - and also in the political debate - quite extensively. A rather common point of criticism, put forward especially by industry associations and the chambers of commerce, refers to the inadequate relation between the projected amount of financial resources and the number of 'urgent' projects. States, as the planning authorities, might have an incentive to underestimate the assumed costs of a project in order to improve its chances to be included into the masterplan. Moreover, past masterplans did not consider inflation. Investment into the federal road infrastructure decreased since the year 2006 when increasing costs for construction are taken into account [6]. The only exception is the year 2009 when the government fought the recession by significantly increasing public investment. If investment into the federal road infrastructure is related to the German GDP, a very similar pattern arises. The highest percentage value can be observed in the year 2009 (with a strong decrease in GDP and an increase in infrastructure investment) whereas this indicator is decreasing after 2010 and shows a minimum in 2015 (own calculations based on federal budget data and GDP data). The share of road infrastructure investment in the overall federal spending varies around $2 \%$ with a maximum in 2009 and generally lower values in the period 2010-2014 when compared to the years 2001-2008 (own calculations based on federal budget data and [43]).

Moreover, past masterplans underestimated the requirements for replacements. Whereas new projects have been included into the masterplan and construction has been started, investment into replacements even stayed below the projected values (again with the exception of the year 2009 - Source: [6]). As a consequence, large parts of the German federal roads require maintenance and replacement investments, this is of particular relevance for bridges, leading to a specific priority program for bridge maintenance and upgrading, set up by the ministry for transport. The new masterplan, enacted in 2016, names the maintenance and replacement of the current infrastructure as its top priority, allocating $69 \%$ of the total funding to this purpose [14]. In the previous masterplans the share of investment into maintaining the existing infrastructure was 56\% (BVWP 2003) and 46\% (BVWP 1992), respectively [11].
Whereas many transport economists as well as stakeholders from the industry criticize lacking funds for additional investment into the transport infrastructure, other transport economists as well as environmental action groups call for a fundamental adjustment of infrastructure masterplanning. According to this position, the focus should be on integrated approaches replacing the 'traditional' orientation towards isolated projects. Additionally, more ambitious targets for changes in the modal split are advocated (e.g. [1]). Compared to the previous masterplan, the share of planned investment into road infrastructure has been slightly reduced (from $52.1 \%$ to $49.3 \%$ ) and is significantly below the share of cars and trucks in the modal split. The share of planned investment into rail infrastructure also decreased (from $42.9 \%$ to $41.6 \%$ ), accompanied by a significant increase in the planned share of investment into federal waterways (from $5.0 \%$ to $9.1 \%$ ) (data source $[11,14])$.

\section{Conclusions}

Although the federal government is responsible for setting the regulatory framework for transport markets as well as for investment into large parts of the German transport infrastructure, there is limited influence of transport policy decision makers. This is due to the fact that European regulations as well as requirements from other parts of the government (e.g. ministry of finance) limit the discretion of transport policy makers. Moreover, the states have a strong influence at least regarding road infrastructure investment, and legal controversies provide additional obstacles. Although the priorities set by policy makers in published transport policy programs have changed, the effects on the overall traffic development remain rather limited. In particular, a shift in the modal split towards more environmental friendly modes of transport, which was a key feature of the integrated transport policy program of the year 2000, has not been achieved. Whereas the integrated transport policy program assumed increasing user costs for road traffic and decreasing user costs for rail traffic, the actual development was different. Moreover, subsequent programs, especially the action plan freight transport and logistics, have shown changing priorities.

With respect to the federal transport infrastructure masterplan, an overestimation of the number of projects which might be completed within the given timeframe has been criticized several times. Although the political progress is providing some incentives to include a high number of projects in the masterplan, a more realistic approach appears to be suitable, also signaling the need for a larger budget. In the past, budget increases have been the result of macroeconomic considerations rather than of transport policy requirements. It remains to be seen whether these deficits will be at least partially eliminated during the lifespan of the recently enacted masterplan. 
Regarding the modal split, the new masterplan is characterized by a decreasing share of investment into the federal road infrastructure and an increasing share of replacement investment, thereby reducing the opportunities for a further expansion of the federal road network.

Open Access This article is distributed under the terms of the Creative Commons Attribution 4.0 International License (http:// creativecommons.org/licenses/by/4.0/), which permits unrestricted use, distribution, and reproduction in any medium, provided you give appropriate credit to the original author(s) and the source, provide a link to the Creative Commons license, and indicate if changes were made.

\section{References}

1. Allianz pro Schiene (2016) Stellungnahme Entwurf Bundesverkehrswegeplan 2030. URL: https://www.allianz-proschiene.de/wp-content/uploads/2016/05/160502_Allianz-proSchiene_Stellungnahme-BVWP-2030-2.pdf

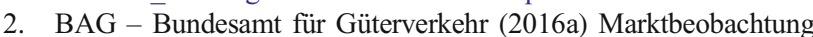
Güterverkehr. Marktanalyse des Fernbuslinienverkehrs 2015, Köln

3. BAG - Bundesamt für Güterverkehr (2016b) Mautstatistik Jahrestabellen 2015, Köln

4. Bergk F et al. (2016) Klimaschutzbeitrag des Verkehrs bis 2050, Umweltbundesamt Texte 56/2016, Dessau-Roßlau

5. Baron T (1995) Transportation in Germany: A historical overview. Transportation Research Part A:Policy and Practice 29(1):9-20

6. Bernecker T, Fichert F (2014) Szenarien für den Finanzierungsbedarf der Verkehrswege des Bundes bis zum Jahr 2030, Stuttgart

7. BMVBS - Bundesministerium für Verkehr, Bau und Stadtentwicklung (2008) Freight transport and logistics masterplan, Berlin

8. BMVBS - Bundesministerium für Verkehr, Bau und Stadtentwicklung (2010) Aktionsplan Güterverkehr und Logistik, Berlin

9. BMVBS - Bundesministerium für Verkehr, Bau und Stadtentwicklung (2011) Bericht zum Stand der Umsetzung des Aktionsplans Güterverkehr und Logistik, Berlin

10. BMVBS - Bundesministerium für Verkehr, Bau und Stadtentwicklung (2012) Aktionsplan Güterverkehr und Logistik - eine Zwischenbilanz, Berlin. URL: http://www.bmvi.de/ SharedDocs/DE/Artikel/G/aktionsplan-gueterverkehr-logistikzwischenbilanz.html?nn=35922

11. BMVBW - Bundesministerium für Verkehr, Bau- und Wohnungswesen (2003) Bundesverkehrswegeplan 2003, Berlin

12. BMVBW - Bundesministerium für Verkehr, Bau- und Wohnungswesen (2000) Verkehrsbericht 2000. Integrierte Verkehrspolitik: Unser Konzept für eine mobile Zukunft, Berlin

13. BMVBW - Bundesministerium für Verkehr, Bau- und Wohnungswesen (ed.) (2000) Verkehr in Zahlen, Hamburg

14. BMVI - Bundesministerium für Verkehr und digitale Infrastruktur (2016) Bundesverkehrswegeplan 2030, Berlin

15. BMVI - Bundesministerium für Verkehr und digitale Infrastruktur (ed.) (2015) Verkehr in Zahlen 2015/16, Berlin

16. BMVI - Bundesministerium für Verkehr und digitale Infrastruktur (2015) Aktionsplan Güterverkehr und Logistik - nachhaltig und effizient in die Zukunft, Berlin
17. BMVI - Bundesministerium für Verkehr und digitale Infrastruktur (2014) Handbuch für eine gute Bürgerbeteiligung. Planung von Großvorhaben im Verkehrssektor, Berlin

18. Bundesminister für Verkehr (1957) Die Verkehrspolitik in der Bundesrepublik Deutschland 1949-1957, Bielefeld

19. Bundesrechnungshof (2014) Öffentlich Private Partnerschaften (ÖPP) als Beschaffungsvariante im Bundesfernstraßenbau, Bonn

20. Bundesregierung (2016) Konferenz der Regierungschefinnen und Regierungschefs von Bund und Ländern am 14. Oktober 2016 in Berlin - Beschluss, Berlin. URL: https://www.bundesregierung.de/ Content/DE/Pressemitteilungen/BPA/2016/10/2016-10-14beschluss-bund-laender.html

21. CDU/CSU/FDP (2009) Wachstum. Bildung. Zusammenhalt. Der Koalitionsvertrag zwischen CDU, CSU und FDP. Berlin

22. Deutsche Bahn AG (2016) Wettbewerbsbericht 2016. Zurück in die Erfolgspur, Berlin

23. Dürr N, Heim S, Hüschelrath K (2016) Deregulation, Competition, and Consolidation: The Case of the German Interurban Bus Industry. Journal of Transport Economics and Policy 50(2):164-188

24. Eurostat (2017) Stock of vehicles at regional level. URL: http://ec. europa.eu/eurostat/statistics-explained/index.php/Stock of vehicles_at_regional_level

25. Evangelinos C (2009) Mauteinführung, Mauterhöhung und Nutzerreaktionen in Deutschland. Wirtschaftsdienst 8:558564

26. Federal Ministry for the Environment, Nature Conversation, Building, and Nuclear Safety (2014) The German Government's Climate Action Programme 2020, Berlin

27. Federal Statistical Office (2015) Germany's Population by 2060. Wiesbaden

28. Fichert F (2010) Verkehrspolitik in der Sozialen Marktwirtschaft. In: Seliger B, Sepp J, Wrobel R (eds) Chancen und Risiken für die Soziale Marktwirtschaft im internationalen Wettbewerb der Wirtschaftssysteme. Frankfurt/M., pp. 71-90

29. Hamm W (1989) Deregulierung im Verkehr als politische Aufgabe, München

30. Heuser T, Reh W (2016) Die Bundesverkehrswegplanung: Anforderungen an die zukünftige Verkehrsinfrastrukturpolitik des Bundes. In: Schwedes O, Canzler W, Knie A (eds) Handbuch Verkehrspolitik, 2nd ed. Wiesbaden, pp. 237-264

31. HMWEVL - Hessisches Ministerium für Wirtschaft, Energie, Verkehr und Landesentwicklung (2015) Jahresbericht zur Genehmigung der Entgeltordnung 2016 des Flughafens Frankfurt, Wiesbaden. URL: https://wirtschaft.hessen.de/verkehr/luftverkehr/ jahresbericht-zur-genehmigung-der-entgeltordnung-2016-desflughafens-frankfurt

32. IBM (2011) Rail Liberalization Index 2011, Brussels

33. IBM (2002) Rail Liberalization Index 2002, Brussels

34. Kalinowska D et al. (2005) Aktualisierung und Weiterentwicklung der Berechnungsmodelle für die Fahrleistungen von Kraftfahrzeugen und für das Aufkommen und für die Verkehrsleistung im Personenverkehr (MIV), Berlin

35. KBA - Kraftfahrt-Bundesamt (2016) http://www.kba.de/DE/ Statistik/Fahrzeuge/Neuzulassungen/Monatliche Neuzulassungen/ monatl neuzulassungen node.html

36. Malina R et al. (2007) Neuordnung der Infrastrukturverantwortung für die Bundesfernstraßen, Münster. URL: http://www. promobilitaet.de/media/file/788.410.Gutachen Foederalismusreform_Fernstrassen.pdf

37. Ministerium für Umwelt, Naturschutz und Verkehr des Landes Baden-Württemberg (2010) Generalverkehrsplan BadenWürttemberg 2010, Stuttgart

38. Monopolkommission (2015) Bahn 2015: Wettbewerbspolitik aus der Spur?, Sondergutachten 69, Bonn 
39. Rothengatter W (2015) BVWP-Bewertungsverfahren: Volle Fahrt zurück in die orthodoxe Neoklassik. Zeitschrift für Verkehrswissenschaft 86(3):181-204

40. Schöller-Schwedes O (2010) The failure of integrated transport policy in Germany: a historical perspective. Journal of Transport Geography 18(1):85-96

41. Statistisches Bundesamt (2017) Verbraucherpreisindizes für Deutschland, Lange Reihen ab 1948, Wiesbaden

42. Statistisches Bundesamt, Several volumes (2017) Preise und Preisindizes für Verkehr, Fachserie 17, Reihe 9.2, Wiesbaden
43. SVR - Sachverständigenrat zur Begutachtung der gesamtwirtschaftlichen Entwicklung (2017) Ausgaben und Einnahmen der staatlichen und kommunalen Haushalte nach Bundesländern. URL: https://www.sachverstaendigenratwirtschaft.de/zr deutschland.html?\&L=0\#c173

44. Walther C, Monse J, Haßheider H (2015) Revision of project evaluation as part of the German Federal transport infrastructure plan. Transportation Research Procedia 8:41-49 